THE FUTURE OF RECRUITMENT 
These leading experts in assessment and technology generously share their insights on the new frontier of talent management tools driven by AI (e.g., video interviews, resume screening, game-based assessments). Authors also raise critically important attendant issues regarding privacy, algorithmic bias, and other legal and ethical concerns. The book stands to contribute to fruitful multidisciplinary collaborations, challenging conversations, and productive disagreements essential to meaningful advances in this domain.

-Dr Fred Oswald, Professor and Herbert S. Autrey

Chair in Social Sciences, Department of Psychological Sciences and Management, Rice University

This book not only describes recruitment technology in a way that is both easy to understand and rich in scientific detail, it also captures the ethical and societal consequences of recruitment. One of the most important books on recruitment to read.

-Frida Polli, CEO and Cofounder of Pymetrics

Everything that's important to know about the future of recruitment is put together in this engaging book which will impact the way we think about recruitment for years to come. New and emerging recruitment technology is expertly captured, if you want to understand the science underlying today's and tomorrow's recruitment tech, look no further.

-Michal Kosinski, Associate Professor of
Organizational Behavior,
Stanford Graduate School of Business 


\section{The Future of Work}

The future of work is a vital contemporary area of debate both in business and management research, and in wider social, political, and economic discourse. Globally relevant issues, including the aging workforce, rise of the gig economy, workplace automation, and changing forms of business ownership, are all regularly the subject of discussion in both academic research and the mainstream media, having wider professional and public policy implications.

The Future of Work series features books examining key issues or challenges in the modern workplace, synthesizing prior developments in critical thinking, alongside current practical challenges in order to interrogate possible future developments in the world of work.

Offering future research agendas and suggesting practical outcomes for today's and tomorrow's businesses and workforce, the books in this series present powerful, challenging, and polemical analysis of a diverse range of subjects in their potential to address future challenges and possible new trajectories.

The series highlights what changes still need to be made to core areas of business practice and theory in order for them to be forward-facing, more representative, and able to fulfill the industrial challenges of the future.

\section{OTHER TITLES IN THE SERIES}

Careers: Thinking, Strategising and Prototyping Ann M. Brewer 
Algorithms, Blockchain and Cryptocurrency: Implications for the Future of the Workplace

Gavin Brown and Richard Whittle

HR without People? Industrial Evolution in the Age of Automation, AI, and Machine Learning

Anthony R. Wheeler and Ronald M. Buckley

The Healthy Workforce: Enhancing Wellbeing and Productivity in the Workers of the Future

Stephen Bevan and Cary L. Cooper

\section{FORTHCOMING TITLES}

Spending Without Thinking: The Future of Consumption

Richard Whittle

Cooperatives at Work

George Cheney, Matt Noyes and Emi Do 


\title{
THE FUTURE OF RECRUITMENT
}

\section{Using the New Science of Talent Analytics to Get Your Hiring Right}

\author{
BY \\ FRANZISKA LEUTNER \\ Goldsmiths, University of London, UK

\section{REECE AKHTAR} \\ Deeper Signals, USA \\ And \\ TOMAS CHAMORRO-PREMUZIC \\ University College London, UK

\section{emerald \\ PUBLISHING} \\ United Kingdom - North America - Japan - India \\ Malaysia - China
}


Emerald Publishing Limited

Howard House, Wagon Lane, Bingley BD16 1WA, UK

First edition 2022

Copyright (C) 2022 by Emerald Publishing Limited

Reprints and permissions service

Contact: permissions@emeraldinsight.com

No part of this book may be reproduced, stored in a retrieval system, transmitted in any form or by any means electronic, mechanical, photocopying, recording or otherwise without either the prior written permission of the publisher or a licence permitting restricted copying issued in the UK by The Copyright Licensing Agency and in the USA by The Copyright Clearance Center. Any opinions expressed in the chapters are those of the authors. Whilst Emerald makes every effort to ensure the quality and accuracy of its content, Emerald makes no representation implied or otherwise, as to the chapters' suitability and application and disclaims any warranties, express or implied, to their use.

British Library Cataloguing in Publication Data

A catalogue record for this book is available from the British Library

ISBN: 978-1-83867-562-2 (Print)

ISBN: 978-1-83867-559-2 (Online)

ISBN: 978-1-83867-561-5 (Epub)

ISOQAR certified

Management System,

awarded to Emerald

for adherence to

Environmental

standard

ISOQAR

ISO 14001:2004.

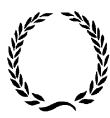

INVESTOR IN PEOPLE 
To my granny Doris and my mother Susanne. May the future continue to afford more opportunities to women

- Franziska Leutner

To my mother Hayley, for her endless support and encouragement

- Reece Akhtar

For those who are trying to make work better

- Tomas Chamorro Premuzic 
This page intentionally left blank 


\section{CONTENTS}

About the Authors

1. The Past, Present, and Future of Recruitment

2. Talent and the Data Science Revolution 17

3. Digital Interviews 51

4. Mining Digital Talent Signals 89

5. Gamification and Game-Based Assessments 119

6. Future of Recruitment 147

7. The Far Future (Possibilities beyond Tomorrow) 171

Index

197 
This page intentionally left blank 


\section{ABOUT THE AUTHORS}

Dr Franziska Leutner is a Lecturer in Occupational Psychology at Goldsmiths College, University of London. She is an organizational psychologist and data scientist and publishes scientific articles on computational psychometrics, gamebased assessments, personality, and entrepreneurship. As a product innovator, she has worked with tech companies and startups to develop the next generation of assessment and selection tools, including at HireVue where she is currently Director of Assessment Innovation. She holds a $\mathrm{PhD}$ from University College London, where she was a lecturer for several years.

Dr Reece Akhtar is a Cofounder and CEO of Deeper Signals. $\mathrm{He}$ is an organizational psychologist and data scientist specializing in applied personality assessment and computational psychometrics. As a lecturer at NYU and researcher at UCL, he has published scientific articles on personality, talent management, leadership, entrepreneurship, and machine learning. Previously he led product innovation at RHR International and Hogan Assessments Systems.

Dr Tomas Chamorro-Premuzic is an international authority in psychological profiling, talent management, leadership development, and people analytics. His commercial work focuses on the creation of science-based tools that improve 
organizations' ability to predict performance and people's ability to understand themselves. He is currently the Chief Talent Scientist at ManpowerGroup, Cofounder of Deeper Signals and Metaprofiling, and Professor of Business Psychology at University College London and Columbia University. He has previously held academic positions at New York University and the London School of Economics, and frequently lectures at Harvard Business School, Stanford Business School, London Business School, and IMD, as well as being the former CEO at Hogan Assessment Systems. Find out more here: www.drtomas.com. 